\title{
Consecutive Treatment of Disulfiram Inhibits Ovarian Carbonyl Reductase Activity in Rats
}

\author{
Nobuhisa Iwata', Norihisa Inazu ${ }^{2}$ and Tetsuo Satoh ${ }^{3}$ \\ 'Division of Xenobiotic Metabolism and Disposition, National Institute of Hygienic Sciences, \\ 18-1. Kamiyoga 1-chome, Setagaya-ku, Tokyo 158, Japan \\ ${ }^{2}$ Department of Pharmacology. Teikyo University School of Medicine. \\ 2-11-I Kaga, Labashi-ku. Tokyo 173, Japan \\ 'Laboratory of Biochemical Pharmacology and Biotoxicology, Faculty of Pharmaceutical Sciences, \\ Chiba University, 1-33, Yayoi-cho, Chiba 260, Japan
}

Received September 27, 1991 Accepted November 19, 1991

\begin{abstract}
We investigated the effects of disulfiram (DS) on ovarian carbonyl reductase activity in rats to determine the influence of DS on female reproductive function. Three consecutive treatments with DS significantly inhibited ovarian carbonyl reductase activity as well as ovulation, dose-dependently. Single treatment with DS had no effect on ovarian carbonyl reductase activity. Our observations indicate that consecutive treatment with DS has an inhibitory action on female reproductive function, although DS is well-known to inhibit aldehyde dehydrogenase and dopamine $\beta$-hydroxylase.
\end{abstract}

We have already reported the properties and regulation of ovarian carbonyl reductasc in rats $(1-5)$. Carbonyl reductase (CR) (EC 1.1.1.184) in rat ovary is a soluble oxidoreductase that catalyzes an NADPH-dependent reduction of the carbonyl group of not only biologically active xenobiotics but also endogenous compounds such as prostaglandins (PGs) and steroids, reducing them to the corresponding alcohols (1). Both the ovarian CR activity, which was measured using 13,14-dihydro-15ketoprostaglandin $\mathrm{F}_{2 \alpha}$ (15KD-PGF $\mathrm{K}_{2 \alpha}$ ) and 4benzoylpyridine (4-BP) as substrates, and the ovarian CR content are linearly increased after the luteinizing hormone ( $\mathrm{LH}$ ) surge (2). In immature rats, the ovarian $\mathrm{CR}$ activity and contents are significantly increased by human chorionic gonadotropin (hCG), and estradiol potentiates the stimulatory effect of hCG; furthermore, tamoxifen, an antiestrogen, antagonizes the action of estradiol on this en- zyme $(3,4)$. On the other hand, we have obscrved by immunohistochemical methods that the ovarian CR in rats is localized in the theca interna cells and the interstitial gland cclls but not found in the granulosa cells (26 ). These facts indicate that rat ovarian CR in androgen producing cells may be regulated by LH and estrogen and involved in ovarian functions.

Disulfiram (DS) which inhibits aldehyde dehydrogenase (EC 1.2.1.3) in the liver has been used for over 30 years in avoidance therapy for patients with chronic alcoholism. In addition, DS is well-known to inhibit various drug metabolizing enzymes including dopamine $\beta$ hydoxylase. Recently, Anderson et al. (7) have reported that gondotropin-induced prolactin release is inhibited by pretreatment with DS in women with polycystic ovary syndrome and suggested that central dopaminergic tone was activated by the suppression of dopamine 
$\beta$-hydroxylase with DS. Furthermore, DS is reported to influence serotonin turnover in rat brain $(8,9)$.

In the present study, we investigated the effects of DS on ovarian CR activity in rats in relation to ovulation.

\section{MATERIALS AND METHODS}

\section{Animals}

Mature Wistar-KY female rats ( 8 weeks old) were purchased from SLC (Shizuoka, Japan), and they were housed in group cages (4 or 5 rats per cage) under controlled conditions of light (12 hours on, 12 hours off) and temperature $\left(23-25^{\circ} \mathrm{C}\right)$. Food and water were administered ad libitum. Only animals that had shown at least two normal 4-day cycles, as determined by daily vaginal smears before the start of the experiment, were used.

\section{Chemicals}

$\left[5,6,8,9,11,12,14-{ }^{3} \mathrm{H}\right] 15 \mathrm{KD}-\mathrm{PGF}_{2 \alpha}$ (sp. act. $80 \mathrm{Ci} / \mathrm{mmol}$ ) was obtained from Amersham International plc (Buckinghamshire, UK), and authentic $15 \mathrm{KD}-\mathrm{PGF}_{2 \sigma}$ was from Upjohn Pharmaceuticals Ltd. (Kalamazoo, MI, USA). 13,14-dihydro-PGF Pa $_{\alpha}$ was kindly provided by Ono Pharmaceutical (Osaka, Japan). Steroids were purchased from Sigma Chemical Co. (St. Louis, MO, USA). Pyridine nucleotide was purchased from Oriental Yeast Co. (Osaka, Japan). Other chemicals or reagent grade were obtained from Wako Pure Chemical Industries (Tokyo, Japan).

\section{Drug treatment}

DS was suspended in $0.5 \%$ carboxymethyl cellulose (CMC) solution. Rats were given DS (200 or $400 \mathrm{mg} / \mathrm{kg}$ ) by consecutive or single oral administration and the concentration of DS was adjusted in the solution so that the final volume given was $2-3 \mathrm{ml}$. Control animals received an equal volume of vehicle (0.5\% CMC solution). dicstrus or on the day of estrus, and the ovaries were immediately isolated and then homogenized in $6 \mathrm{ml}$ of $10 \mathrm{mM}$ phosphate buffer (pH 6.5) containing $0.154 \mathrm{M} \mathrm{KCl}, 1 \mathrm{mM}$ dithiothreitol, $0.1 \mathrm{mM}$ EDTA and $1 \mu \mathrm{M}$ phenylmethylsulfonyl fluoride. The ovarian homogenate was centrifuged at $105000 \times g$ for $60 \mathrm{~min}$ at $4^{\circ} \mathrm{C}$, and the $105000 \times \mathrm{g}$ supernatant (cytosolic fraction) was obtained as a crude enzyme preparation. In the case of estrous rats, oviducts were examined for the presence of ova under a dissecting microscope.

\section{Enzyme assay}

Ovarian CR activity was measured using 4-BP, 15KD-PGF $2 \alpha$ 4-nitroacetophenone (PNAP), menadione, 4-nitrobenzaldehyde (PNBA), $5 \alpha$-androstanedione, and $5 \alpha$-dihydrotestosterone $(1,2)$. The reductase activity was determined spectrophotometrically by measuring the oxidation rate of NADPH at $340 \mathrm{~nm}$ with a Hitachi 150-20 spectrophotometer at $37^{\circ} \mathrm{C}$. The standard assay mixture consisted of ovarian cytosol, substrate, 0.1 mM NADPH and $100 \mathrm{mM}$ phosphate buffer $(\mathrm{pH} 6.5)$ in a total volume of $1.0 \mathrm{ml}$. One unit of the enzyme was defined as the amount that catalyzed the oxidation of $1 \mu$ mole NADPH at $37^{\circ} \mathrm{C}$. The reduction of $15 \mathrm{KD}-\mathrm{PGF}_{2 \alpha}$ was radiochemically determined by measuring $\left[{ }^{3} \mathrm{H}\right] 13,14-\mathrm{H}_{2}-\mathrm{PGF}_{2 \alpha}$ formed from $\left[{ }^{3} \mathrm{H}\right] 15 \mathrm{KD}$ $\mathrm{PGF}_{2 \alpha}$ as described by Inazu et al. (10). The reaction mixture consisted of ovarian cytosol, $\left[{ }^{3} \mathrm{H}\right] 15 \mathrm{KD}-\mathrm{PGF}_{2 \alpha}(283$ pmoles $/ 0.05 \mu \mathrm{Ci}), 1 \mathrm{mM}$ NADPH and $100 \mathrm{mM}$ phosphate buffer $(\mathrm{pH}$ 7.0). The cytosolic protein was determined by the method of Lowry et al. (11) after separating interfering materials according to the method of Bensadoun and Weinstein (12).

\section{Statistical analysis}

All results were expressed as means \pm S.E. Student's $t$-test was used for comparison between groups, with $\mathbf{P}$ values of 0.05 or less considered to indicate a significant difference.

\section{Enzyme preparation}

Rats were sacrificed on the second day of 


\section{RESULTS}

Effects of three consecutive treatments with DS on tissue weight, ovulation and ovarian CR activity were investigated. DS (200 and $400 \mathrm{mg} / \mathrm{kg}$ ) was orally administered for three days from the first day of diestrus, and the rats were sacrificed 24 hours after the final treatment with DS. Table 1 shows changes in the ovarian and uterine weights in relation to ovulation. Treatment with $400 \mathrm{mg} / \mathrm{kg}$ of DS resulted in a significant decrease in body wcight and ovarian wcight, and both 200 and $400 \mathrm{mg} / \mathrm{kg}$ of DS complctely inhibited ovulation. The ovarian $\mathrm{CR}$ activities towards various substrates after treatment with DS are summarized in Table 2 . The reductase activities towards $15 \mathrm{KD}-\mathrm{PGF}_{2 \alpha}, 4-\mathrm{BP}, 5 \alpha$-androstanedione and $5 \alpha$-dihydrotestostcrone were significantly decreased by 200 and $400 \mathrm{mg} / \mathrm{kg}$ of DS to $60-70 \%$ and $50-60 \%$ of the control values, respectively. In contrast, menadione reductase activity was increased 2 -fold by consective DS treatment $(400 \mathrm{mg} / \mathrm{kg})$. Consecutive DS treatment had no effect on the reduction of either PNAP or PNBA in the ovarian cytosol of estrous rats.

To determine the effect of a single administration of DS, a $400 \mathrm{mg} / \mathrm{kg}$-dose of DS was given to diestrous or proestrous rats at 9:00 a.m., and then the ovaries were isolated 24 hours later. Table 3 shows changes in body weight, tissue weights, and ovarian CR activity. Body weight, ovarian and uterine weights did not change and ovulation was not inhibited by single treatment with DS to procstrous rats. Ovarian CR activity was not appreciably affected by DS with the exception of PNBA reductase activity (Table 4).

\section{DISCUSSION}

We have already demonstrated that both the activity and contents of ovarian CR are increased by hCG and estrogen potentiated this stimulatory effect of hCG (1-6), and we also found that nonsteroidal antiestrogen and glucocorticoids significantly decrease both the activity and contents of ovarian CR as well as inhibition of ovulation $(13,14)$. These facts indicate that the level of ovarian $\mathrm{CR}$ may be closely linked to ovarian function, especially the ovulatory process.

DS is well-known to inhibit dopamine $\beta$ hydroxylase in brain tissue as well as aldehyde dchydrogenase (15). On the other hand, dopamine is established to inhibit prolactin release from the pituitary gland $(16,17)$, and L-dopa treatment significantly decreased serum prolactin (18). Prolactin is reported to have a direct inhibitory effect on follicular estradiol production in rats (19). These results suggest that dopamine increased by an inhibition of dopamine $\beta$-hydroxylase with DS may influence release and production of pituitary prolactin, gonadotropin, and ovarian estrogen.

Single treatment with DS had no effect on the parameters tested here. Fukumori et al. (8) has reported that single treatment with DS $(200 \mathrm{mg} / \mathrm{kg}$, i.p.) does not inhibit soluble aldehyde dehydrogenase and monoamine oxidase activity, but significantly decreases mitochondrial aldehyde dehydrogenase activity in rat brain. Thus, these results indicate that DS may not have an effect on the hypothalamo-pituitary ovaian axis by single treatment in this study.

We have found that DS strongly inhibits the activity of CR purified from rat ovary (1). Accordingly, it is thought that DS has inhibitory effects on both dopamine $\beta$-hydroxylase and ovarian CR. However, three consecutive treatments with DS caused not only a significant decrease in CR activity, body weight, ovarian and uterine weights but also inhibition of ovulation. At present, we can not explain away the present results on three consecutive treatments with DS on the basis of dopamine elevation and prolactin decrease by the inhibition of dopamine $\beta$-hydroxylase. It appears that DS may inhibit gonadotropin, especially the LH surge before ovulation, and estrogen release. The ambiguity suggests that there may be other factors in the brain and the reproductive system which respond to DS. Nevertheless, it is obvious that long term treatment 
Table 1. Effects of three consecutive treatments of disulfiram on body wcights and the ovarian and uterine weights in rats

\begin{tabular}{lrcc}
\hline & $\begin{array}{c}\text { Control } \\
\text { (vehicle only) }\end{array}$ & \multicolumn{2}{c}{ Disulfiram } \\
& $(200 \mathrm{mg} / \mathrm{kg})$ & $(400 \mathrm{mg} / \mathrm{kg})$ \\
\hline Body weight $(\mathrm{g})$ & $199.2 \pm 3.7$ & $195.8 \pm 4.6$ & $171.3 \pm 4.3^{* *}$ \\
Ovarian weight $(\mathrm{mg})$ & $78.6 \pm 2.5$ & $64.0 \pm 2.74^{* *}$ & $67.3 \pm 1.70^{* *}$ \\
Uterine weight $(\mathrm{mg})$ & $272.2 \pm 7.5$ & $265.3 \pm 17.4$ & $236.5 \pm 15.25$ \\
No. of ova & $13 \pm 0.5$ & 0 & 0 \\
\hline
\end{tabular}

Disulfiram $(200$ or $400 \mathrm{mg} / \mathrm{kg}$ ) was administered p.o. to rats at 9:00 a m. for three days from the first day of diestrus. After measuring body weights of rats, the ovary and utcrus were immediately isolated and weighed at $24 \mathrm{hr}$ after the last treatment. Each value shows a mean \pm S.E. ${ }^{* *}$ Significantly different from the control $(\mathrm{P}<$ $0.01)$.

Table 2. Effects of three consecutive treatments of disulfiram on ovarian carbonyl reductase activities in rats

\begin{tabular}{|c|c|c|c|}
\hline & \multirow{2}{*}{$\begin{array}{c}\text { Control } \\
\text { (vehicle only) }\end{array}$} & \multicolumn{2}{|c|}{ Disulfiram } \\
\hline & & $(200 \mathrm{mg} / \mathrm{kg})$ & $(400 \mathrm{mg} / \mathrm{kg})$ \\
\hline \multicolumn{4}{|l|}{ Reductase activity } \\
\hline $\begin{array}{l}15 \mathrm{KD}-\mathrm{PGF}_{2 \alpha} \\
(\mathrm{pmol} / \mathrm{mg} \text { protein } / 15 \mathrm{~min})\end{array}$ & $337.2 \pm 14.3$ & $215.7 \pm 39.5^{*}$ & $170.0 \pm 6.9^{* * *}$ \\
\hline $\begin{array}{l}\text { 4-Benzoylpyridine } \\
\text { (nmol/mg protein/min) }\end{array}$ & $17.62 \pm 0.52$ & $10.13 \pm 1.88^{* *}$ & $8.61 \pm 0.45^{* * *}$ \\
\hline $\begin{array}{l}\text { 5 } \alpha \text {-Androstanedione } \\
(\mathrm{nmol} / \mathrm{mg} \text { protein/min) }\end{array}$ & $2.72 \pm 0.37$ & $1.92 \pm 0.63$ & $1.15 \pm 0.26^{*}$ \\
\hline $\begin{array}{l}\text { 5 } \alpha \text {-Dihydrotestosterone } \\
\text { (nmol/mg protein/min) }\end{array}$ & $9.11 \pm 0.83$ & $6.38 \pm 0.20^{*}$ & $4.65 \pm 0.55^{* *}$ \\
\hline $\begin{array}{l}\text { Menadione } \\
\text { (nmol/mg protein/min) }\end{array}$ & $66.0 \pm 7.06$ & $130.9 \pm 13.0^{* *}$ & $143.3 \pm 3.66^{* * *}$ \\
\hline $\begin{array}{l}p \text {-Nitroacetophenone } \\
\text { (nmol/mg protein/min) }\end{array}$ & $111.1 \pm 5.90$ & $104.4 \pm 4.49$ & $108.0 \pm 3.97$ \\
\hline $\begin{array}{l}p \text {-Nitrobenzaldehyde } \\
(\mathrm{nmol} / \mathrm{mg} \text { protein } / \mathrm{min})\end{array}$ & $209.4 \pm 8.49$ & $218.9 \pm 8.69$ & $215.0 \pm 3.49$ \\
\hline
\end{tabular}

Rats were treated as described in Table 1 . At $24 \mathrm{hr}$ after the last treatment, the animals were sacrificed, ovarian cytosols were prepared, and the enzyme activities were determined, as described in Materials and Methods. Each value shows a mean $\pm S$.E. * Significantly different from the control $(\mathrm{P}<0.05) .{ }^{*}$ Significantly different from the control $(\mathrm{P}<0.01) . * * *$ Significantly different from the control $(\mathrm{P}<0.001)$. 
Table 3. Effects of single administration of disulfiram on body weights and the ovarian and uterine weights in rats

\begin{tabular}{|c|c|c|c|c|}
\hline & \multicolumn{2}{|c|}{ Experiment 1} & \multicolumn{2}{|c|}{ Experiment 2} \\
\hline & $\begin{array}{c}\text { Control } \\
\text { (vehicle only) }\end{array}$ & $\begin{array}{l}\text { Disulfiram } \\
(400 \mathrm{mg} / \mathrm{kg})\end{array}$ & $\begin{array}{c}\text { Control } \\
\text { (vehicle only) }\end{array}$ & $\begin{array}{l}\text { Disulfiram } \\
(400 \mathrm{mg} / \mathrm{kg})\end{array}$ \\
\hline Body weight (g) & $198.0 \pm 2.2$ & $199.5 \pm 4.4$ & $197.8 \pm 1.0$ & $201.0 \pm 3.7$ \\
\hline Ovarian weight (mg) & $79.3 \pm 1.9$ & $81.0 \pm 1.5$ & $83.5 \pm 1.4$ & $86.3 \pm 1.9$ \\
\hline Uterine wcight (mg) & $219.0 \pm 6.5$ & $218.0 \pm 4.2$ & $275.8 \pm 12.4$ & $272.5 \pm 11.1$ \\
\hline No. of ova & - & - & $10 \pm 0.5$ & $11 \pm 0.7$ \\
\hline
\end{tabular}

Experiment 1: Wistar-KY female rats were given disulfiram $(400 \mathrm{mg} / \mathrm{kg})$ by single oral administration on the first day of diestrus. Experiment 2: Rats were given disulfiram $(400 \mathrm{mg} / \mathrm{kg}$ ) by single oral administration on the day of proestrus. After measuring body weights of rats, the ovary and uterus were immediately isolated and weighed at 24 hr after the treatment. Each value shows a mean $\pm S$.E.

Table 4. Effects of single administration of ovarian carbonyl reductase activities in rats

\begin{tabular}{|c|c|c|c|c|}
\hline & \multicolumn{2}{|c|}{ Experiment 1} & \multicolumn{2}{|c|}{ Experiment 2} \\
\hline & $\begin{array}{c}\text { Control } \\
\text { (vehicle only) }\end{array}$ & $\begin{array}{l}\text { Disulfiram } \\
(400 \mathrm{mg} / \mathrm{kg})\end{array}$ & $\begin{array}{l}\text { Control } \\
\text { (vehicle only) }\end{array}$ & $\begin{array}{l}\text { Disulfiram } \\
\text { (400 } \mathrm{mg} / \mathrm{kg} \text { ) }\end{array}$ \\
\hline \multicolumn{5}{|l|}{ Reductase activity } \\
\hline $\begin{array}{l}15 \mathrm{KD}-\mathrm{PGF}_{2 \alpha} \\
(\mathrm{pmol} / \mathrm{mg} \text { protein } / 15 \mathrm{~min})\end{array}$ & $172.5 \pm 15.9$ & $169.2 \pm 18.0$ & $312.6 \pm 37.3$ & $269.9 \pm 17.3$ \\
\hline $\begin{array}{l}\text { 4-Benzoylpyridine } \\
\text { (nmol/mg protein/min) }\end{array}$ & $9.09 \pm 0.78$ & $7.71 \pm 0.88$ & $15.3 \pm 0.89$ & $12.8 \pm 0.80$ \\
\hline $\begin{array}{l}\text { 5a-Androstanedione } \\
\text { (nmol/mg protein/min) }\end{array}$ & $1.62 \pm 0.48$ & $1.26 \pm 0.33$ & $3.58 \pm 0.23$ & $3.21 \pm 0.26$ \\
\hline $\begin{array}{l}5 \alpha \text {-Dihydrotestosterone } \\
(\mathrm{nmol} / \mathrm{mg} \text { protein } / \mathrm{min})\end{array}$ & $3.40 \pm 1.68$ & $2.59 \pm 1.00$ & $1.09 \pm 0.39$ & $1.13 \pm 0.37$ \\
\hline $\begin{array}{l}\text { Menadione } \\
\text { (nmol/mg protein } / \min \text { ) }\end{array}$ & $59.1 \pm 4.56$ & $50.3 \pm 0.53$ & $64.8 \pm 3.15$ & $70.3 \pm 6.81$ \\
\hline $\begin{array}{l}p \text {-Nitroacetophenone } \\
\text { (nmol/mg protein/min) }\end{array}$ & $57.9 \pm 1.21$ & $63.7 \pm 3.46$ & $84.6 \pm 7.46$ & $86.3 \pm 2.87$ \\
\hline $\begin{array}{l}p \text {-Nitrobenzaldehyde } \\
\text { (nmol/mg protein/min) }\end{array}$ & $188.6 \pm 7.33$ & $173.0 \pm 7.50$ & $202.3 \pm 2.19$ & $238.7 \pm 5.04^{* * *}$ \\
\hline
\end{tabular}

Rats were treated as described in Table 3 and the enzyme activities were determined, as described in Materials and Methods. Each value shows a mean \pm S.E. *** Significantly different from the control $(\mathrm{P}<0.001)$. 
with DS decreases some ovarian and uterine functions. Rat ovarian $\mathrm{CR}$ catalyzed the reduction of $\mathrm{PGE}_{2}$ to $\mathrm{PGF}_{2 \alpha}$ as well as the reduction of $15 \mathrm{KD}-\mathrm{PGF}_{2 \alpha}$ to $13,14-\mathrm{H}_{2}-\mathrm{PGF}_{2 a}$ (1). $\mathrm{PGF}_{2 \alpha}$ is well-known to be a luteolytic factor and to have an action of uterine contraction. 13,14- $\mathrm{H}_{2}-\mathrm{PGF}_{2 \alpha}$ also possesses a luteolytic action in heifer (20) and stimulated steroidogenesis in vitro (21). The present results that DS inhibited directly or indirectly ovarian CR activity mean the decrement of reproductive function in female rats.

Carbonyl reductase as well as aldehyde reductase (EC 1.1.1.2) and aldose reductase (EC 1.1.1.21) belong to the aldo/keto reductase family (22). In this study, the effect of DS on PNBA reductase activity was different from other reductase activities tested. Recently, we have purified aldose reductase from rat ovary and demonstrated that ovarian aldose reductase shows higher affinity for PNBA than ovarian CR (23). Thus, PNBA reductase activity in rat ovary may depend on aldose reductase and aldehyde reductase rather than $C R$. As shown in this study, the regulation of these reductases may be also different from ovarian CR. On the other hand, only menadione reductase activity was increased by consecutive treatment of DS. A possible explanation for this observation is that DT-diaphorase (EC 1.6.99.2) in rat ovary is induced by DS. In fact, this activity was inhibited by dicoumarol, a potent inhibitor of DT-diaphorase (24) (data not shown). However, the physiological role of DT-diaphorase in the ovary is still unknown.

Further investigations to determine the mode of action of DS on ovarian CR and reproductive system are in progress.

\section{REFERENCES}

1 Iwata, N., Inazu, N. and Satoh, T.: Purification and characterization of NADPH-dependent carbonyl reductase from rat ovary. J. Biochem. 105, $556-564$ (1989)

2 Iwata, N., Inazu, N. and Satoh, T.: Changes in rat ovarian carbonyl reductase activity and content during the estrous cycle, and localization. Biol. Reprod. 42, $161-166$ (1990)

3 Inazu, N., Inaba, N. and Satoh, T.: Immunohistochemical localization and physiological regulation of carbonyl reductase in immature rat ovary. Japan. J. Phamacol. 54, 15-21 (1990)

4 Inazu, N., Inaba, N. and Satoh, T.: Regulation of ovarian carbonyl reductase mediated by estrogen receptor in immature rats. Biochem. Pharmacol. 40, 2495-2502 (1990)

5 Iwata, N., Inazu, N. and Satoh, T.: Changes and localization of ovarian carbonyl redutcase during pseudopregnancy and pregnancy in rats. Biol. Reprod. 43, 397-403 (1990)

6 Inazu, N., Inaba, N. and Satoh, T.: Localization and regulation of ovarian carbonyl reductase in rats. Prog. Clin. Biol. Res. 290, 323-334 (1989)

7 Anderson, R.E., Barnces, R.B., Ben-Rafael, Z., Rosen, G.F., Flickinger, G.L., Lobo, R.A. and Meloni, F.: Secretory dynamics of bioactive and immunorcactive prolactin in polycystic ovary syndrome. Fert. Steril. 49, $239-243$ (1988)

8 Fukumori, R., Minegishi, A., Satoh, T., Kitagawa, H. and Yanaura, S.: Effect of disulfiram on turnover of 5-hydroxytryptamine in rat brain. Life Sci. 25, $123-130$ (1979)

9 Minegishi, A., Fukumori, R., Satoh, T., Kitagawa, H. and Yanaura, S.: Changes in serotonin turnover and the brain sensitivity to barbiturates by disulfiram treatment in rats. Res. Commun. Chem. Pathol. Pharmacol. 24, 273-287 (1979)

10 Inazu, N., Iwata, N. and Satoh, T.: Enzymatic properties of 13,14-dihydroprostaglandin $\mathrm{F}_{2 \alpha}$ synthetase in ovarian cytosol of the rats. Res. Commun. Chem. Pathol. Pharmacol. 55, 25-38 (1987)

11 Lowry, O.H., Rosebrough, N.J., Farr, A.L. and Randall, R.J.: Protein measurement with the Folin phenol reagent. J. Biol. Chem. 193, 265-275 (1951)

12 Bensadoun, A. and Weinstein, D.: Assay of proteins in the presence of interfering materials. Anal. Biochem. 70, 241-250 (1976)

13 Inazu, N., Inaba, N., Kogo, H. and Satoh, T.: Physiological role of ovarian carbonyl reductase and effect of antiestrogen on its activity in rats. Res. Commun. Chem. Pathol. Pharmacol. 63, $341-359$ (1989)

14 Inazu, N., Iwata, N. and Satoh, T.: Inhibitory effect of glucocorticoid and stimulatory effect of human chorionic gonadotropin on ovarian carbonyl reductase in rats. Life Sci. 46, 841-848 (1990)

15 Goldstein, M., Anagnoste, B., Lauber, E. and 
McKereghan, M.R.: Inhibition of dopamine $\beta$ hydroxylase by disulfiram. Life Sci. 3, 763-767 (1964)

16 MacLeod, R.M. and Lehmeyer, J.E.: Studies on the mechanism of the dopamine-mediated inhibition of prolactin secretion. Endocrinology 94. 1077 - 1085 (1974)

17 Shaar, C.J. and Clemens, J.A.: The role of catecholamines in the release of anterior pituitary prolactin in vitro. Endocrinology 95, 1202-1212 (1974)

18 Wiggins, J.F. and Fernstrom, J.D.: L-Dopa inhibits prolactin secretion in proestrous rats. Endocrinology 101, 469-474 (1977)

19 Uilenbroke, J.Th.J. and van der Linden, R.: Effects of prolactin on follicular oestradiol production in the rat. J. Endocrinol. 102, 245-250 (1984)
20 Milvae, R.A. and Hansel, W.: Luteolytic effect of 13,14-dihydro-PGF ${ }_{2 \alpha}$ in heifers. J. Reprod. Fertill. 67, 203-207 (1983)

21 Inazu, N., Kogo, H. and Aizawa, Y.: Effect on 13,14-dihydroprostaglandin $F_{2 a}$ on steroid biosynthesis in rat ovary. Japan. J, Pharmacol. 31, 301303 (1981)

22 Felsted, R.L, and Bachur, N.R.: Mammalian carbonyl reductases. Drug Metab. Rev. 11, 1-60 (1980)

23 Iwata, N., Inazu, N. and Satoh, T.: The purification and properties of aldose reductase from rat ovary. Arch. Biochem. Biophys. 282, 70-77 (1990)

24 Ernster, L.: DT-Diaphorase. Mcthods Enzymol. 10, $309-317$ (1967) 